\title{
UnPaCKING a National HeRoINE: Two KARTINIS AND THEIR PEOPLE
}

\author{
Danilyn Rutherford
}

As Head of the Country, I deeply regret that among the people there are still those who doubt the heroism of Kartini. ... Haven't we already unanimously decided that Kartini is a National Heroine? ${ }^{1}$

On August 11, 1986, as Dr. Frederick George Peter Jaquet cycled from Den Haag to his office in Leiden, no one would have guessed that he was transporting an Indonesian national treasure. The wooden box strapped to his bicycle looked perfectly ordinary. When he arrived at the Koninklijk Instituut voor Taal-, Land- en Volkenkunde, the scholar opened the box to view the Institute's long-awaited prize: a cache of postcards, photographs, and scraps of letters sent by Raden Adjeng Kartini and her sisters to the family of Mr. J. H. Abendanon, the colonial official who was both her patron and publisher. From this box so grudgingly surrendered by Abendanon's family spilled new light on the life of this Javanese nobleman's daughter, new clues to the mystery of her struggle.

Dr. Jaquet's discovery, glowingly reported in the Indonesian press, was but the latest episode in a long series of attempts to liberate Kartini from the boxes which have contained her. For decades, Indonesian and foreign scholars alike have sought to penetrate the veils obscuring the real Kartini in order to reach the core of a personality repressed by colonial officials, Dutch artists and intellectuals, the strictures of tradition, and the tragedy of her untimely death. The promise and the mystery of Kartini have given rise to a fluorescence of questions on all aspects of her life. Why did she give up her plans to go to Holland? Did she really predict her own death? Was she a feminist or a nationalist? Is Indonesia living up to her dreams? ${ }^{2}$ President Suharto's pronouncement notwithstanding, Kartini has sparked a conversation which seems unlikely to cease.

\footnotetext{
1 President Suharto in "Ayunda Tidak Pernah Menyerah," Tempo, December 12, 1987, p. 23.

2 See Cora Vreede de Stuers, "Kartini, Petit 'Cheval Sauvage' Devenu Heroine de L'Independence Indonesienne," Archipel 13 (1977): 105-17; and Kartini Centenary: Indonesian Women Then and Now (Melbourne: Monash University, 1980) on Kartini's feminist credentials. To learn what Kartini would think of today's Indonesia, see Satu Abad Kartini (Jakarta: Grafitas, 1979).
} 
Whence the enthusiasm, the obsession with Kartini? From her birth on April 21, 1879 to her death in childbirth in 1904, Kartini scarcely ventured beyond the borders of the community in which she was raised. When she died, she left little behind except a handful of essays and a series of letters written to Dutch penpals during the last four years of her life. ${ }^{3}$ The obvious origin of Kartini's importance lies with those Dutch friends, who presented the young Javanese, with her flowing Dutch prose, as an emblem of the benefits of enlightened colonial rule. After Kartini's death, Abendanon compiled and edited some of her letters, which he published in Holland in 1911 under the title, Door Duisternis Tot Licht or "From Darkness into Light." Aggressively promoted by Abendanon and other ethici, who used the proceeds to fund a charity in her name, the book quickly became a best seller. It had already reached its third edition in 1912. Translations in English (1920), Arabic (1926), Japanese (1955), and French (1960) followed, 4 along with the Volkslectuur version of 1922, Habis Gelap Terbitlah Terang, ${ }^{5}$ through which the colonial state introduced Kartini to the generation of Malay-educated schoolchildren who would live to identify her with the founding of their nation. 6

Kartini the heroine was born in this process of translation as the truth beckoning from beyond the texts. While the lure of translation keeps Kartini alive, the institutions which produced and disseminated her stories have more to do with her heroism than the insights her letters may contain. But this is not to say that the debates about the "real" Kartini are without significance. We can learn a great deal by examining the Kartini that various periods in history have produced. In plumbing Kartini's heart, writers stake a political claim to a powerful symbol. To appropriate Kartini for a certain nation, party, class, or gender, writers must present a convincing answer to a simple question. Who are Kartini's people? Who did this heroine rightfully represent?

Pramoedya Ananta Toers' Panggil Aku Kartini Saja and Sitisoemandari Soeroto's Kartini, Sebuah Biografi 7 provide two answers to this question. On a number of points their responses agree. Both writers claim Kartini for the Indonesian people as a pioneer of their yet-to-bediscovered nation. Both argue that Kartini's colonial patrons obscured the true power of her thought. Yet their views of Kartini's people and her thought are as different as the historical contexts in which they wrote. While their Kartinis may not embody all of the differences between the Old Order and the New Order, they reflect an important shift in legitimating

\footnotetext{
${ }^{3}$ In addition to "Educate the Javanese," discussed later in this article, Kartini's published works include "Een Gouverneur Generaalsdag," which appeared in De Echo in 1900, and "Van een Vergeten Uithoekje," published in Eigen Haard in 1903. Her earliest published work, "Het Huwelijk bij de Kodja's," was an ethnographic depiction written by the sixteen-year-old Kartini for the 1895 edition of Bijdragen tot de Taal-, Land-en Volkenkunde van Nederlandsch-Indie.

4 Sulastri Sutrisno, "Kata Pengantar," in Surat-surat Kepada Ny. R.M. Abendanon-Mandri dan Suaminya Jakarta: Djembatan, 1989), pp. XIX, XVIII.

${ }^{5}$ Pramoedya describes plans by the leadership of Perhimpunan "Jong Java" to translate Kartini's letters into Javanese, Sundanese, Madurese, and Balinese. According to Pramoedya, this project, discussed in the 1920s, never materialized. The first "local language" translations Pramoedya mentions are R. Sutjidibrata's Sundanese edition, published in 1930, and Ki Sastrasugunda's Javanese edition, published in 1938. See Pramoedya Ananta Toer, Panggil Aku Kartini Sadja: Sebuah Pengantar pada Kartini, 3 vols. (Jakarta: Nusantara, 1962), 2: 131. According to the foreword to the 1922 edition of Habis Gelap Terbitlah Terang, Dr. Abendanon himself asked the Volkslectuur committee to produce a Malay translation.

${ }^{6}$ Simamora describes one woman's memory of reading Kartini when she was growing up during the 1920s. Ibu Aruji went on to found a women's battalion during the National Revolution. Ibu Aruji's memories have as much to do with Kartini's present status as with her impact in the past. See Satu Abad Kartini, pp. 145-50.
}

7 Jakarta: Gunung Agung, 1977. 
ideologies. Pramoedya locates his Kartini and her people in a history of struggle. Soeroto locates hers in the naturalized categories and boundaries of the State.

\section{The History of the Books}

Before turning to the texts, it seems worth pausing for a moment on their construction. On the surface, the books have much in common. The tables of contents cover a similar range of topics: Kartini's background, the era in which she lived, her thoughts on colonial society, the later impact of her work. Both books are written in Indonesian with smatterings of Dutch, English, and Javanese. Both writers end each chapter with extensive footnotes, listing foreign scholars, interviews with Kartini's family, and her letters to substantiate their claims. Both Pramoedya and Soeroto begin their books by describing what inspired them to undertake research on Kartini. Both present their project as a long and arduous task.

It is in this account of origins that the differences between the books begin to come into view. Pramoedya, recognized by many as Indonesia's greatest living writer, published his introduction to Kartini's life and thought in 1962, three years before the violent demise of Soekarno's Old Order. Pramoedya saw his book as part of the struggle of the new Indonesian nation to free its history from colonial frames. Composed at the turn of the century, Kartini's letters gave Pramoedya a place to begin to rewrite his nation's past from the perspective of the ruled. Confined to Java by a dearth of resources and time, Pramoedya spent from 1956 to 1961 scouring the National Archives and National Museum in Jakarta, and gathering materials from private libraries, newspapers, and Kartini's son. As informants died and documents vanished, Pramoedya conducted his research as a race against time. Only with the financial and moral support of Indonesian friends and institutions could he endure the four long years it took to complete the work.

Soeroto, who published her biography in 1977, gives her mission a different twist. Fortune and patriotism launched this journalist and mother on her career as a biographer. Driving with her husband from Jakarta to Central Java in March of 1964, Soeroto got a sudden urge to stop in Salatiga to interview Kardinah, the late Kartini's younger sister, for a feature on Kartini's birthday. The inspiring picture Kardinah painted was confirmed that May when Sukarno made Kartini an official National Hero. It was an embarrassment to the nation that no one had written Kartini's biography, Soeroto concluded. Somehow, she worked up the courage to embark on a task that no Dutch nor Indonesian scholar had dared to undertake. Since there were "no Indonesian books on Kartini,"8 most of Soeroto's material came from Holland, including her copy of Door Duisternis Tot Licht, called by Soeroto "DDTL." A chance encounter with Rob Nieuwenhuys in 1971 brought her a trunk-load of his research notes to use in her efforts; other Dutch scholars sent materials as well. Soeroto interviewed Kartini's family, as well as General Nasution, who told her many "amusing stories" about Kartini's son's exploits in the army. After four years of research, Soeroto had nearly ruined her eyesight, but her task was complete. Immediately popular, Soeroto's book was lauded as a "monumental" work by Bouman, a respected scholar of Kartini and one of the Dutch sources Soeroto cited.

We can learn something from the ways in which Pramoedya and Soeroto attempt to validate their findings. Pramoedya's task was to capture those glimpses of Kartini which

\footnotetext{
${ }^{8}$ That is, according to Soeroto. When she began the project in 1964, a number of Indonesian works on Kartini had already been published. Subandrio's brief account of Kartini appeared in 1950; Pramoedya's three-volume "introduction" came out in 1962. Soeroto lists Pramoedya in her bibliography, but she does not mention his book in her text. It was after 1965 that Pramoedya's books became scarce; this paper can only illustrate indirectly the reasons why.
} 
had slipped through the net of Dutch scholarship. While he may not have had "hard" facts to replace them, he challenged the conclusions of foreign "experts." Soeroto's task was to combine the experts' conclusions and piece together Kartini with all of her glory intact. Dutch scholarship proves Kartini's virtues; if foreigners think so highly of Kartini, should not Indonesians feel the same? Soeroto collected, verified, and interpreted all of her data, but the emphasis was clearly on collection. With Soeroto's book being cited by the next round of Kartini revisionists, ${ }^{9}$ her "facts" are recycled in yet another form.

Differences in method aside, both Pramoedya and Soeroto attempt to use their evidence to reveal the real Kartini behind the myth. In Soeroto's text, the myth is that Kartini was a "goddess," not a living woman who was great enough to inspire a nation. Her goal is to show those instances where, despite her greatness, Kartini suffered and faltered too. In Pramoedya's text, the myth is two-fold: Indonesians either reject Kartini as a colonial product or accept her as a nationalist without knowing why. His goal is to show that Kartini was the first "Indonesian thinker" able to represent her people in modern terms. Soeroto presents the facts that make Kartini a real person and even more glorious for this reason. Pramoedya presents the contradictions which created Kartini's consciousness and the Indonesian nationalism which followed. By demystifying Kartini, both contend that they will reveal a woman with a relationship to her people much stronger than the myths imply.

\section{Kartini's Heritage}

This feeling developed in Kartini's heart, because she knew that in the field of progress, she was their valid heir. She felt called by history to work for eternity, to serve the people (rakyat) of her country. Without a doubt, it is clear that this call, indistinct or clear, had also been heard by her forebears. ${ }^{10}$

Didn't Kartini, as a descendent of Tjondronegoro, have a right to be a pioneer, to be an example knocking on the door of the old fashioned world that impeded the current of progress? Progress not just for women, but for men too so that both would move forward and the Javanese people (bangsa) would be perfected? ${ }^{11}$

The first step in uniting Kartini with her rightful people is to anchor her firmly in the past. For both Pramoedya and Soeroto, the key to the "real" Kartini lies in her connection with a distant, glorious epoch. As a hero of the Indonesian nation, Kartini is heir to its tradition; from the legitimating soil of national myth grows Kartini's family tree. It takes some creative pruning, but both Pramoedya and Soeroto manage to graft the branches on which their Kartinis will bloom.

\footnotetext{
9 Alisa Thomson Zainu'din, "Kartini-Her Life, Her Influence," in Kartini Centenary leans heavily on Soeroto.

10 Pramoedya, Panggil Aku Kartini Saja, 1: 32.

11 Soeroto, Kartini, Sebuah Biografi, p. 74. Throughout this article, I will call attention to the different ways that Pramoedya and Soeroto translate what appears in Kartini's texts as the Dutch term "volk." John M. Echols and Hassan Shadily's An Indonesian-English Dictionary (Ithaca: Cornell University Press, 1961) defines rakyat (then rakjat) as "people, the populace, public" (p. 257). Variations include "rakyat jelata," "the masses, the common people, proletariat," and "rakyat jembel," "the poor." Bangsa is given eight definitions, including "nation, people," "race," "nationality," "family, category, sex," "social class, group," "type," "kind" and "breed" (p. 30). These words have significantly different political connotations. Pramoedya's vocabulary evokes the people as "public," a "populace" united in a struggle against common oppression. Soeroto's evokes the people as a "family," bound by the innate, taken-for-granted ties that link creatures of one "race," "breed," or "type." The relationship of these different terms to Pramoedya and Soeroto's very different Kartinis should become clear in the course of this article. For now, one should keep in mind who is speaking wherever these words appear. "Rakyat" and "bangsa" first gained political currency well after Kartini's death. "Rakyat" and "bangsa" are Pramoedya and Soeroto's words; they could not have been Kartini's.
} 
In Soeroto's case, the task is straightforward. Inventively interpreting the genealogies of Javanese kings, she fixes Kartini's roots in Majapahit, the Indies' most powerful precolonial state. Fourteen generations back, Soeroto discovered a paternal ancestor, Prabu Bromowijoyo, who could connect Kartini with the New Order's cartographical forebear. Much is at stake in this cartography, and Soeroto takes an angry detour to refute Berg's claim that Majapahit extended no further than East Java. Majapahit's boundaries have to have equaled the borders of modern Indonesia to prove the new state's historical legitimacy. Destiny placed Kartini within these ancient boundaries, and destiny had a hand in her nationalism, which is also grounded in concrete, timeless truths. While Soeroto generally defers to the "proof" presented by Western scholars, this particular scholar has to be wrong.

Pramoedya also links Kartini to the ancient past, but he proceeds somewhat differently. Soeroto begins with blood lines and ends with a geography unsullied by the influence of the Dutch. Pramoedya begins with geography and ends with the blood spilled by rebels who fought to keep Jepara free. Pramoedya returns not to Majapahit, but to Mataram, the last Javanese kingdom to resist the Dutch East Indies Company, and depicts a long line of princes who made a stand. Her struggle links Kartini to those who preceded her; she is legitimated through conflict, not through the map. As the heirs to this spirit of resistance, Kartini and her people find their true bond.

Where Soeroto writes of Java's ancient era, we see an image of beauty and tranquility. "Molek, indah, kaya raya," Majapahit was a land of art and music, of peaceful and respectful relations between the rulers and the ruled. Colonial domination disrupted this pretty picture by stripping Java's leaders of their prestige. Under the rule of the Dutch, the Javanese degenerated. Apathetic and ignorant, they simply waited for commands and sat back while their new masters sucked their land and their spirit dry.

Against this depressing backdrop, Kartini's grandfather rose like a shining star in the colonial bureaucracy. Recognizing his talents, the Dutch rapidly promoted Tjondronegoro IV to positions of responsibility and authority, granting him his father's title at the tender age of twenty-five. From his vantage point as Bupati of Demak, Tjondronegoro IV saw the unhappiness around him and asked himself, "How did we fall so far behind?" The answer was obvious: a lack of education was to blame. So he taught himself Dutch and strove to enlighten his family and his inferiors. He hired a Dutch governor to teach his children science; he himself attended to their morals, promoting the age-old virtues of Javanese culture. His efforts paid off: not only were his sons respected servants of the Dutch and of their people, they were accomplished linguists and scholars to boot. Honored with Dutch medals for their service, Kartini's grandfather and uncles bequeathed her a spirit of service and duty, along with the intellect her letters would later reveal.

When Pramoedya writes of Kartini's predecessors, he paints a more turbulent picture. Precolonial society was not governed by peace, but by a crude form of feudalism in which the people exchanged their freedom for protections in times of war. With the pacification of Diponegoro, the relations between the people and their leaders took a different form. Kartini's grandfather fought for his people through "reports and administration," no longer able to wage open combat. ${ }^{12}$ Whereas for Soeroto's Tjondronegoro, colonialism is the cause of ignorance, for Pramoedya's, ignorance is the cause of colonialism. Instead of "Why are we stupid?", he asks himself "How did we lose?" Pramoedya's Tjondronegoro answers "Western science," but he turns it towards different ends. Service and knowledge are not

12 Pramoedya, Panggil Aku Kartini Sadja, vol. 1, p. 24. 
Kartini's birthright; it is the battle for the people which she is destined to carry forward into the era of the modern colonial state.

But Pramoedya does more than insert Kartini's noble forebears into the parade of Javanese heroes. He inserts her maternal ancestors into a parade of their own, aligning Kartini not only with the people's defenders, but with the people themselves. In Kartini's genealogy flow the competing streams of nineteenth-century colonial feudalism and twentieth-century capitalist exploitation. Kartini's mother was born in Jepara to the foreman of a private sugar factory. This grandfather belonged to the first generation of laborers produced when Holland liberalized the Indies economy. Where Soeroto brushes aside Kartini's mixed blood, Pramoedya makes it a key element in her consciousness. His Kartini inherited her father's love for learning, but she inherited more than her nose from his lower-class wife. Personal conflict and her society's contradictions gave Kartini a reason to leave her noble status behind, and to say "Just call me who I am."

\section{Kartini's Childhood}

As his children grew up, Bupati Sosroningrat always cared for their spiritual development. ... From their earliest years, he made a habit of bringing them on his visits to the villages, so they would understand the lives of the little people [rakyat kecil] and a feeling of love towards them would grow. ${ }^{13}$

Kartini's nursemaid was domestic strife, a polygamous struggle. ${ }^{14}$

Their genealogies complete, Old Order Kartini and New Order Kartini are ready to enter the scene. Our two Kartinis descended from very different forebears; they had very different childhoods as well. Where Soeroto paints a picture of domestic bliss, documenting Kartini's happy progress under her father's care, Pramoedya presents us with the stress of her mixed heritage, portraying the conflict between the common and the noble that drove Kartini into her father's care. Their early experiences prepared the two heroines for different relations with their people and different perspectives on the system in which they lived.

Drawing on Kardinah's memories, Soeroto recounts New Order Kartini's early years in richly detailed episodes. From the very beginning Kartini was ahead of her age. At eight months, she was inquisitive and adroit; at nine, she showed intellect and a talent for observation; at twelve, maternal instincts and a strong sense of justice. Soeroto intersperses these episodes with the series of rituals that Kartini's family - "who held rightly to Javanese tradition"15_performed for the young heroine. With these stories, Soeroto not only demonstrates Kartini's talents; she shows her acting and speaking Javanese, albeit with an adorable lisp.

Soeroto's tapestry of mundane facts reinforces the "reality" of New Order Kartini and locates her in the timeless world of Javanese culture. Her childhood is thoroughly imaginable for a good New Order Javanese. Of course, Kardinah could hardly have witnessed all of these events, but who could have invented such stories? What's more, with this happy picture, Soeroto negates any link between Kartini's common parentage and her later nationalism. Ngasirah's status was both legal and public; Kartini and the children of the noble wife were treated alike; the two wives got along well. The children may have spoken to Ngasirah in low Javanese, but their relations were perfectly cordial. It was Mr. Abendanon,

13 Soeroto, Kartini, p. 37.

14 Pramoedya, Panggil Aku Kartini Sadja, vol. 1, p. 58.

${ }^{15}$ Soeroto, Kartini, p. 31. 
in an effort to appeal to a European audience, who deleted the Bupati's second wife from Kartini's letters. Kartini herself had nothing to hide. In all, the picture is a pretty one; just as in the days of Majapahit, what a pleasant life the family must have led!

Dispensing with her mother, Soeroto traces New Order Kartini's charitable sentiments directly to her father. It was Sosroningrat who took Kartini and her sisters to the villages and cultivated their love for the poor. Again relying on Kardinah's memory, Soeroto weaves a myriad of details around the trips: the expedition to see the fire victims, the travels through the flooded lands, the free banquets on Idul Fitri appear in sharp relief. We can almost see the gratitude on the faces of the happy peasants, the pleasure on the faces of the noble girls. The impact of this upbringing is clear. Soeroto writes:

We can see how, thanks to the guidance of her father, a high priyayi with a feeling of responsibility and love for the people, the noble daughters from their earliest days were close to the lives of the people and how this implanted in them a love for their People [Bangsa], their brown skinned race, a feeling which throughout their lives could not be shaken by their friendship with the Dutch, no matter how close. . . . Cultivated in Kartini and in her younger sisters, this love directly influenced her as an adult, so in the end it became her goal to carry her People [Bangsa] in the direction of Progress and Welfare! ${ }^{16}$

Passed down from her father, Kartini's concern for her people is part and parcel of the selfless nobility of her ancestors. The Dutch may bring modern temptations, but New Order Kartini can resist their charms.

Old Order Kartini did not have the benefit of such an unproblematic upbringing. From the beginning, her life was rent by conflict. Her mother, Ngasirah, was valued for her body, not her birth or etiquette; the Bupati kept her outside the main house, far from the gaze of disapproving visitors. Between Ngasirah and the Bupati's noble wife, the Raden Ayu, there was little love lost. Kartini stayed out of the cross-fire by turning to her father for companionship; Ngasirah finally left or was ordered away. Kartini's relationship with her stepmother never warmed; her relationship with her real mother was cut short. Through her father and her brother young Kartini gained the love and wisdom she craved.

These childhood tensions led to new contradictions when Kartini's father introduced her to the colonial world. One day, during a visit to the villages, the family met a young grasscutter. Kartini looked from the grass-cutter to her young nephew, seeing their similarities and the gap between their lives. Her heart went out to the boy, yet she could not blame the person directly responsible for his suffering, for that person was her beloved father. In a flash, Kartini grasped the roots of her mother's suffering and the inhumanity which she now witnessed: the enemy was the system, not the people within it. What served in Soeroto's account as one more example of Bupati Sosroningrat's lessons becomes Old Order Kartini's moment of awakening.

Old Order Kartini's heroism lies in her ability to transcend the contradictions of her life and experience. Torn between love and justice, she produces a critique of the linguistic hierarchy which prevents people from communicating as human beings. Soeroto's Sosroningrat connects New Order Kartini to her people by teaching her the importance of noblesse oblige. Pramoedya's Sosroningrat separates Old Order Kartini from her people, but in the process creates the conditions which lead her to enlightenment. That her critique comes to focus on the status of women does not undermine Pramoedya's argument. Kartini's pledge to "work" for the "people" ("rakyat") marks the failure of feudal categories:

16 Ibid., p. 31. 
noble women should never "work," especially not for the common folk. In confounding these categories, Kartini lays important foundations.

From her sharp observation come not just knowledge and insight, but honest love for them which in the end will develop into patriotism: that is wide, positional Nationalism! 17

\section{Kartini's Confinement}

Maybe Kartini, with her education, was destined to become the woman to have her eyes opened by seeing the DARK world here and the LIGHT world there. ${ }^{18}$

Where Old Order Kartini "awoke" through a forbidden identification with the rakyat, New Order Kartini had to leave the outside world to harken to her calling. New Order Kartini's happy days as a mischievous, carefree girl ended abruptly at puberty. Like other noble girls of the time, Kartini could not appear again in public until she was safely married. New Order Kartini suffered bitterly in her "gilded cage." Cut off from the classroom she loved, contemplating the horrors of marriage to a perfect stranger, she often thought of death. Yet it was suffering and confinement that led to this Kartini's enlightenment. While trapped in the house, she devoured books and newspapers, she listened to her father's conversations, she scrutinized the behavior of his guests. She had long hours to absorb all that she read and observed. In short, "she became an adult before her time!"19

As New Order Kartini reflected on her position, she thought of the other girls who were suffering the same fate. Why had no one spoken out against the excesses of feudalism? Something had to be done. Inspired by the memory of her grandfather, Kartini experienced a renaissance of the spirit. The struggle in her soul between the forces of modernity and feudalism finally tilted in favor of the Light. She would be the one to take up the battle to improve the position of women, all to the glory of their people! She would work for her people to save other girls from her fate.

She wanted to change the situation that she could no longer bear. She wanted with all her soul, because she was driven by a feeling of responsibility to devote her life to humanity-to decrease the suffering of Woman through the Progress of her People [Bangsa]!20

Old Order Kartini had already experienced enlightenment when she entered the gilded cage, but her suffering served to deepen her dedication. Given her relationship with her father, the field of women's education became an arena where Kartini could declare battle on feudalism without challenging his prestige. Suffering deepened her awareness, but it did not form it. Pramoedya insists that his nation's obsession with the tragic in Kartini's life only obscures the full meaning of her thought.

\section{Kartini Leaves the Cage}

Their awakening complete, our two Kartinis were prepared to confront the world and present their program for change. After their release from confinement, the Kartinis pursued somewhat different goals, even if their activities were identical. New Order Kartini was revolutionary but respectful, holding fast to the good priyayi values her father taught

\footnotetext{
${ }^{17}$ Pramoedya, Panggil Aku Kartini Sadja, vol. 1, p. 115.

18 Soeroto, Kartini, p. 74.

${ }^{19}$ Ibid., p. 71.

${ }^{20}$ Ibid., p. 75.
} 
her. Old Order Kartini used her grasp of Dutch language and Javanese art to fight the colonial system, pushing to their limits the boundaries which her environment presented her.

New Order Kartini began her campaign at home by freeing her sisters from the rules of respect. She put her studies into practice and built a personal regime on the basis of "Kemerdekaan, Persamaan, Persaudaraan," that is, Liberté, Egalité et Fraternité. 21 The territory of this new nation did not extend far. Revolutionary slogans aside, the regime deferred when it came to her parents, for Kartini recognized the respect her elders deserved. Her critique of Dutch officials who demanded Javanese deference focused on their greed and inauthenticity, not on the colonial hierarchy itself. These men were "gila hormat," or "crazy for respect"; they succumbed to their desires, just like the greedy bupati who excessively extracted the "cultuurprocent." How unnatural it was for the Dutch not to want people to speak to them in their own language. Javanese "happily use kromo inggil, the highest speech level, to those of their bangsa with a higher status"; having to speak it with a foreigner who responds in "market Malay" puts them to shame.22

Given her upbringing, New Order Kartini had no trouble differentiating between good and bad uses of Javanese. Nor, it seems, did she find it difficult to recognize good and bad Malay. The good uses of Dutch were particularly obvious. Dutch gave Indonesian a way to order from the menu of foreign knowledge. Entrees as complex as the French Revolution could be served up in perfect Indonesian as long as one knew the code. For all the importance of this code, New Order Kartini knew that it could never fulfill the need for character and culture. Following her father's training and her ancestors' wisdom, she gave her people modern knowledge, but at the same time promoted Javanese values. This program is clear in her Note on education: schools should teach Dutch, but they should give priority to the students' mother tongue. ${ }^{23}$ New Order Kartini may have "liked" Dutch, but she clearly knew its place.

Old Order Kartini confronted a more complex set of problems in her work for the rakyat. She had to choose her audience and the language in which she would address them. For New Order Kartini, Dutch was as transparent as a contact lens and no more likely to distort. For Old Order Kartini, Dutch was a politically charged weapon which had to be handled with care. Through Dutch, Old Order Kartini could enter the European world and criticize its occupants; she could represent the rakyat's demands. Her writing could reach educated pribumi, allowing them to look at the Indies objectively and change what they saw. Kartini saw the potential of Malay, Pramoedya insists, but recognized that this language of gossip badly needed reform. ${ }^{24}$ Used by Dutch officials to shame their Javanese counterparts, Malay created colonial barricades, not doors, as Kartini saw when she compared it to Czech. ${ }^{25}$ Soeroto marvels that New Order Kartini even knew about Russia. ${ }^{26}$ Pramoedya gives his Kartini an international awareness of the place of language in social struggle.

Both Kartinis put their visions into action through their work with Javanese artisans. Once again, the two women defined their project very differently. New Order Kartini inherited her love of Javanese art as a matter of course. Her father had taught her the beauty

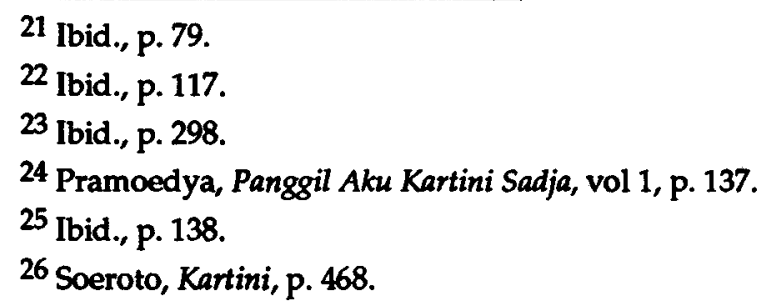


of her culture, its roots in the past, and the responsibility of "introspective patrons" to show their people its true meaning. ${ }^{27}$ High culture, like the boundaries of the state, harkened back to legitimating origins. The duty of the elite was to preserve authenticity, keeping "Java" in its original shape.

Old Order Kartini also found the truth of her people in their art, but she saw this relationship very differently. Connotations, not denotations, gave art its value; historical experience gave culture its meaning. The gamelan was more than specifically Javanese music. It called to mind Kartini's ancestors and their brave and valiant deeds. The gamelan could also evoke a glorious future when the struggle would begin anew. Because of this connection between art and resistance, Kartini made the promotion of Javanese handicrafts a political activity. She not only saved the wood carvers from exploitation, she protected and cultivated their voice. In addition to preserving their identity, art could improve the people's character. By "returning art to the people in an improved form," education made the people strong. ${ }^{28}$ As Pramoedya writes:

For the first time in the history of Modern Indonesia, a person knew the function of art for education, and art as a way of knowing the character of the people, even their history in dark eras gone by. 29

Unlike New Order Kartini, who valued culture as if it were a fixture of nature, Old Order Kartini saw art as the product of her people's struggle, an essential element of their character, won in history, not given by fate.

\section{Kartini is Silenced}

Neither Pramoedya nor Soeroto gave their story a happy ending. Both Kartinis rejected scholarships and married polygamists for the sake of their ailing fathers. Both eventually died in childbirth, their voices silenced, their ambitious plans permanently deferred. This series of tragedies followed a series of betrayals by people they loved and trusted. New Order and Old Order Kartini faced a similar set of villains, but these villains had differing motives for their deeds.

The "human tragedy" of New Order Kartini can be traced to the fateful day she gave up her plans to study in Holland. The colonial government, through her trusted Mr. Abendanon, engineered her downfall. With her other Dutch friends, Abendanon could accept Kartini's criticism as long as she remained in the Indies because it came from such a "pure and honest heart." 30 But if Kartini had gone to Holland, who knows what would have happened? If Kartini was brave enough to confront the Dutch while under their control, who knows what she might have said if freed? Her alliance with Van Kol, the prominent Social Democrat, literally raised red flags. Abendanon later felt guilty, but that day on Klein Scheveningen he had no choice but to persuade Kartini not to go.

While the colonial government was to blame, New Order Kartini was not without responsibility for her fate. She could have rejected her patron's advice; she could have forged ahead. By wavering at the moment when her dream was in reach, Kartini paved the way to her marriage and her death; she would always regret this decision. Yet Soeroto embraces this "flaw" in Kartini which opens her to tragedy and pain. God's Will determined Kartini's

\footnotetext{
27 Ibid., p. 115.

${ }^{28}$ Pramoedya, Panggil Aku Kartini Sadja, vol. 1, p. 118.

29 Ibid.

${ }^{30}$ Soeroto, Kartini, p. 121.
} 
destiny, but her sacrifice for her sick father is a natural response which makes Kartini even more sublime. With Cora Vreede de Stuers, Soeroto wonders if perhaps it was a good thing that Kartini died young. Abendanon might never have published DDTL if he had not felt remorse at her death. Would Kartini have meant as much to her nation if she had lived happily to a ripe old age?

While the incident on the beach sealed New Order Kartini's fate, Abendanon muffled her voice once again when he compiled DDTL. He edited freely to avoid offending the Kartini Fund's potential donors. We may never know the full scope of Kartini's criticism of the Dutch, nor of her awareness of the plots they mounted to thwart her. Many of her friends refused to cooperate with Abendanon; some even burned Kartini's letters. Luckily there are other sources of information to add to our picture of Kartini, even if we can never know her completely.

Old Order Kartini was censored too, but her repression began much earlier. Abendanon and her father never took her seriously. The Dutch government never bothered to read her "Note on Education," which Annie Glaser neglected to send to Holland. To the Dutch, "Kartini was like a coffee tree that produced well out of Dutch efforts to 'civilize' Indonesiansserved up in all her sweetness ever since they began Dutch primary schools." 31 If Abendanon prevented her trip for political reasons, this led to no moral crisis; his fascination with Kartini was political from the start. Of course Abendanon's compilation of her letters paints a distorted picture; the Malay version published by the Dutch blurs her image even more. Both books omit many of Kartini's letters to Stella, the socialist and feminist who was Kartini's most radical friend. These letters must have undermined the Dutch image of Kartini the tragic but grateful victim by introducing Kartini the fighter.

But the Dutch were not the only force which kept Old Order Kartini under wraps. In Pramoedya's version of his heroine's tragedy, an internal censor is a work as well. Kartini's decision to betray her convictions sprang in part from her relationship with her father. But this is not a victory of "natural" affinities; the tragedy was necessary, given Kartini's location in the history of her nation's consciousness. If Kartini had had a wider base of support, if she had been able to get closer to her real people, her life might have ended differently. But Kartini would never have understood the system had it not been for the contradictions in her soul. Love and conflict enabled Kartini to see her world through different eyes and to "humanize humanity," in the words of her hero Multatuli. ${ }^{32}$ Love for her father, whom she would not yet deny, brought this struggle to an end.

\section{Kartini Becomes a National Pioneer}

What occurred after New Order Kartini's death can hardly come as a surprise, given Soeroto's foreshadowing. We are told by page XVII what will be proven in the end: Kartini embodied the spirit of nationalism "YEARS BEFORE THE FOUNDING OF BOEDI

OETOMO IN 1908!"33 Should we doubt this claim, we can flip to the speech that the leaders of De Indische Vereniging gave in Leiden in 1911 as soon as they had read DDTL. ${ }^{34}$

Kartini's life so inspired these Indonesian students that they pledged to make her words their guiding light. This light did not fail their organization. The Vereniging survived the decade to become the Perhimpunan Indonesia under Mohammad Hatta and other

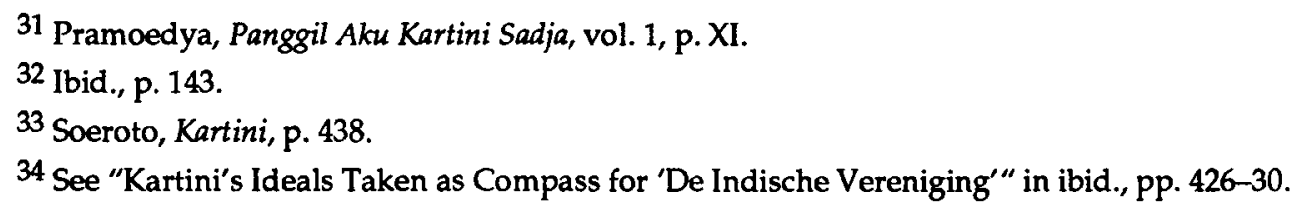


"pioneers of our independence." 35 For the Father of the Revolution, Kartini's spirit steered a course through the Sumpah Pemuda to the War of National Liberation. Even today's family planning program can claim Kartini as its ancestor; her critique of the Regent with fiftythree wives is simply "Two are enough!" in a slightly different guise. ${ }^{36}$

If this trajectory is not enough to prove Kartini's nationalist credentials, Soeroto can turn to her heroine's sisters, who give a first-hand account of Kartini's spirit and its miraculous journey. Kartini's essence spread by contact and worked its way into everyone's soul. "We younger siblings carried on our older sister's work because her struggle was in our blood." 37 Her ideas percolated through the Indies, finally reaching the educated youth whom Kartini inspired to unite. Kardinah recalls:

A feeling of uplift was in the air. Everywhere sparks of the national movement had begun to appear. We always struggled to keep these sparks alive, until several years later appeared the movement that was later named the Nationalist Movement. ${ }^{38}$

Can there be any doubt that Kartini was its cause?

If we are still not convinced that Kartini was indeed the "pioneer of National Progress," the work of foreign scholars should persuade us. Soeroto lines up excerpts from George Kahin, W. F. Wertheim, J. S. Furnivall, and J. Th. Petrus Blumberger to testify to Kartini's role as the "MOTHER OF NATIONALISM," a fact which should not upset men because, after all, "mothers gave birth to us." 39 "If well-known scholars say Kartini was a precursor of nationalism, based on proof, how can we not value her as much?"40

Pramoedya's historical method is somewhat more sophisticated: just because Kartini preceded later nationalists, Pramoedya does not claim that she inspired them. While Pramoedya credits Old Order Kartini as the first modern Indonesian thinker, her position at a particular juncture in history made her so. In the transition from forced-labor feudalism to modern bureaucracy, two phenomena were born: one was the Ethical Policy, a new instrument of colonial control, and the other was nationalism, the child of colonial education which would grow up to reject its parent. As the marker of this transition, Kartini deserves a place in history, whether or not there were concrete connections between Kartini and the revolutionaries who followed her.

Old Order Kartini may not have "caused" the national awakening, but her thought reflected the forces that would shape it. She followed Malay newspapers and knew of the expanding ranks of educated youth. She advocated reforming Malay, bringing the accuracy

35 Soeroto, Kartini, p. 404.

36 Ibid., p. 421.

${ }^{37}$ Letter from Ibu Kardinah to Soeroto, April 1984, ibid., p. 420.

38 Ibid., p. 421.

${ }^{39}$ See ibid., p. 413. "That a woman in fact progressed first need not disappoint Indonesian men. For whoever truly feels like a nationalist should be proud...precisely because the one who pioneered the rise of our nationalism was a woman [seorang wanita]: the class of mothers [kaum ibu] who gave birth to us..." Replacing "a woman", "seorang wanita," with "the class of mothers", "kaum ibu," Soeroto makes the "MOTHER" of Indonesia out of a young woman generally portrayed as objecting to this equation.

40 Ibid., pp. 438-39. Soeroto begins this chapter with a much more modest claim. "Many well-known foreign scholars do not forget to mention Kartini and her role in their books." In fact, Kartini appears in the excerpts which "prove" Soeroto's point as a symptom of Western education, one factor among others responsible for the development of nationalism. This does not concern Soeroto. Her logic makes the historical symptom into the Mother of the Nation; best of all, these scholars have hard facts and esteemed reputations to back them up. 
of her beloved Dutch to this language that would become Indonesian. She planned to write for the colonial press. "It has always been my intention to raise a loud voice," she wrote, "because only publication can bring the improvements that we wish in this situation which so badly needs uplifting." 41 Had Old Order Kartini lived to participate in the movement, she might have cooperated with leaders who later challenged the feudalism she abhorred. Even if Kartini only reached Indonesians through Door Duisternis Tot Licht, her thought heralded their nation's birth and its contradictions. Pramoedya writes:

She knew that, at this time, she was the product of feudal upbringing with her father as the law and the source of law, representing not only the King but the Gods. Kartini was not going to disappoint her father or reduce his right over her as his daughter. But she was also aware of the future which had to be seized with effort and with struggle.42

Kartini had to accept her tragedy, but she anticipated what history was to bring.

\section{Who are Kartini's People?}

What insights can we gain from Soeroto and Pramoedya's answers to our original question? Explicitly or implicitly, who did and do these fine young women represent?

For New Order Kartini, the people were not a problem; she came by her constituency quite naturally. By inheriting her father's refined values, she came to love the rural people and care for their welfare; through suffering, she took up the fight to free other women so they could participate in this charitable mission. Kartini had no need to choose between rakyat or ningrat; all Indonesians, whether common or noble, could find their true identity in her family's virtues, the legacy of Majapahit, and the map. With these virtues to guide her, New Order Kartini proceeded with her social program. She fought colonial temptations and criticized those who gave in. She revealed those whose desire and inauthenticity upset the natural order, whether the culprit was the "prestige crazy" Dutchman or his greedy native underling. Unlike modern Indonesian girls, New Order Kartini was never tempted to imitate the West. With an ancient, authentic map to guide her, her path and her people remained clearly in the light.

Old Order Kartini came by her people more painfully. Where New Order Kartini suppressed imagination -saving plenty for Soeroto and her "facts" - Old Order Kartini found her people in a battle between identification and compassion. This Kartini may have inherited her spirit of resistance from her ancestors, but her role as the mouthpiece of the rakyat sprang from the contradictions of her life. Her earliest experiences in a feudal household helped her to imagine the poor. The tension between her love for the people and her love for her father led Kartini to attack the foundations of the colonial hierarchy, not just its excesses. Where her grandfather was a reformer, Old Order Kartini was a radical, her identity grounded in struggle with the colonial power. In the dawn of a new era, Kartini did not just adopt a pre-existing position; she created her consciousness anew.

But this discussion of differences neglects a common feature of our two Kartinis. By presenting them in English, I have obscured the fact that both Kartinis inhabit an Indonesian language world. Old Order Kartini's Rakyat (people) differ from New Order Kartini's Bangsa (people, nation or race) and her Masyarakat (community or society); all three differ from the Dutch Volk or the American (We The) People. As markers of regimes with their own ideologies and agendas, these words each have a special salience. Soeroto's vocabulary

\footnotetext{
41 Pramoedya, Panggil Aku Kartini Sadja, vol. 2, p. 97.

42 Ibid., p. 185.
} 
cannot help but call to mind the destruction of the social forces which took Pramoedya's vocabulary as their emblem. For all their differences, these words serve a common purpose: they create a Kartini who writes in Dutch but thinks in Indonesian, a Kartini whose pen does not create, but reveals. In their search for origins, Pramoedya and Soeroto generate mythical figures. Grounding Kartini's people in place and in history, Pramoedya and Soeroto translate into Kartini's letters what they imagine must be there: a nation and a language waiting to be found.

\section{Beyond the New Order: Historical Kartini and her Texts}

When we consider recent Indonesian history, our two Kartinis reveal much more than the fantasies of very different minds. Old Order Kartini and her New Order sister tell us much about Indonesia before and after the victory of the post-colonial state over civil society, a counter-revolution described by Ben Anderson in his essay, "Old State, New Society." ${ }^{43}$ Their characters call to mind the languages employed by Soekarno and Suharto, one signifying perpetual revolution, the other motionless order. To understand how these idioms have fared, we need only consider the fate of our two Kartinis' creators. Twenty-five years after his detention, Pramoedya is still under house arrest in Jakarta; his books remain banned. ${ }^{44}$ Soeroto travels freely with her historian husband, giving speeches and granting interviews to the Indonesian press. ${ }^{45}$

The ideological gap between the two Kartinis should come as little surprise. What seems more intriguing is the ease with which Pramoedya and Soeroto used identical excerpts to support very different arguments. Kartini, as a collection of letters, seems open to infinite readings. New Order Kartini may reign in today's Indonesia, but elsewhere other Kartinis have made their debut. Depicting the continuities, not the breaks, between the current and the colonial regime, these new Kartinis can tell us something of the features which have made Kartini such a durable symbol.

"In Her Historical Context" Kartini is a good example of the new generation. The latest in Jean Taylor's creations (which include "Far Reaching Policies" Kartini and "Child of Feminism" Kartini), 46 she spoke for the daughters of noblemen struggling to maintain their place in a changing society. This Kartini found her home at the dawn of an era when improved technology created new types of colonists who lived much more briefly in the Indies. With their wives and children, these officials and entrepreneurs created European enclaves, safe from the "inlanders" whom they regarded with curiosity and fear. To mix with their new masters, Javanese officials needed wives with European graces; ambitious fathers taught their daughters Dutch to prepare them for the task. Taylor's Kartini was a product of this process. Like Djajadinigrat, another "modern" priyayi of her day, Kartini

${ }^{43}$ Benedict Anderson, Imagined Communities: Reflections on the Origin and Spread of Nationalism (London: Verso, 1983).

44 See William Watson's introduction to his translation of Pramoedya's "Bukan Pasar Malam," in Indonesia 15 (April 1973): 21-26.

45 See Hanna Rambe, “Sejenek Bersama Sitisoemandari," in Satu Abad Kartini, pp. 109-14.

46 Taylor's work exemplifies our heroine's ongoing demystification by academics. See Jean Gelman Taylor, "Educate the Javanese," Indonesia 17 (April 1974): 83-98, where she calls Kartini's thoughts on education "wideranging," "enlightened," and "highly visionary," in that her position "moved beyond that of her society, which by leaders comprehended only men." In Taylor's "Raden Adjeng Kartini," Signs: Journal of Women in Culture and Society 1, no. 3, pt. 1 (pp. 639-61), Kartini's most important contribution becomes her ability "to apply the doctrine of then contemporary feminism to her own society." Taylor's latest essay, "Kartini in Her Historical Context," Bijdragen tot de Taal-, Land-en Volkenkunde 145, 2/3 (1989): 295-307, casts a different light on Kartini by comparing her with a man of her class rather than other leaders of her gender. 
presented an elite response to the demands of the modern colonial state. Her goals and her ability to formulate them arose from the sociological conditions of her time; her dream was to educate the members of her class so that they could fill the shoes of the Dutch.

Tsuchiya Kenji's "Keroncong" Kartini occupies a position in discourse as well as in history. This Kartini combined Dutch nostalgia and modern "science"; she was both a product and a producer of cultural idioms. While Taylor sheds some light on the letters' social context, Tsuchiya dissects the elements of Kartini's texts which make her a candidate for a nationalist reading. With Pramoedya, Tsuchiya argues that Kartini represents the "first modern element in Indonesian intellectual history," 47 yet he explains aspects of Kartini's consciousness that Pramoedya takes as given. Looking at Kartini's prose, not her policies, Tsuchiya places Kartini at the end of the "empty years" following the demise of the last Javanese court poet. The conflicting strains in Kartini's character are not ningrat and kromo, but sentiment and realism. Writing at the beginning of the modern era, Kartini created herself and her people by using Dutch to bring her world into view.

In Kartini's letters, she used her Dutch telescope to differing effects. Focused on the natural landscape, Keroncong Kartini painted sentimental pictures in space. Taking the transcendent viewpoint of a theosophical God, Kartini evoked a beauty anyone could claim. Like keroncong music and hindia molek art, these sentimental prose pictures mirrored the consciousness of the Dutch of the time: their nostalgia for an imagined past in a period of rapid change, their ambiguous attachment to this land they so briefly made their home. Focused on the social landscape, Kartini presented a biting critique of colonial society. No longer is hers a perspective that anyone can occupy; it is a vision that creates an "us" and a "them." Kartini's greatest contribution was to synthesize the social and the aesthetic, bringing words and images together to plant the seeds of a national consciousness. No longer the beautiful Indies, the place was Java, a cultural landscape unique to a people and a time. "Almost accidentally" the idiom for a new imagined community arose; it was Kartini, in her isolation, who first explored this position between Dutch and Javanese and brought this new idiom into being.

The most interesting elements of Keroncong Kartini are features that other Kartinis lack. Tsuchiya points to Kartini's loneliness as a Javanese viewing her society from outside the Javanese language world. Because of Kartini's isolation, the community she directly encountered was limited indeed; she had few companions who could share her point of view. Without this community, Kartini could never fix herself at the end of her lens; her writing is often garbled and repetitive as a result. For all their crises, New Order Kartini and Old Order Kartini enjoy a stable identity, a peculiarly Javanese soul. Tsuchiya's Kartini has to stake a claim on this soul, and its stability cannot be assured.

Perhaps more importantly, Tsuchiya points to an awkwardness between Kartini and the common people that neither Pramoedya nor Soeroto seems to note. Missing from the Indonesian versions are the strange stares that met Kartini during her jaunts to the villages in her father's motor car. Kartini imagined herself living in a hut, and relished the novelty of the notion; it was "as if" her sister were one of the workers precisely because it was not the case. It was colonial language, not personal experience, that allowed Kartini to imagine the people's soul; for Kartini, as for the "heroes" who followed her, a strangeness about the people remained. One of Holland's legacies to the new nation was Javanology, a science which made Dutch the revealer of the "truth" of Java; Kartini saw her people through a

47 Pramoedya, Panggil Aku Kartini Sadja, p. XIII. See also Kenji Tsuchiya, "Kartini's Image of the Javanese Landscape," East Asian Cultural Studies 25, 1-4 (1986): 60. 
Javanological screen, but she felt the excess the Dutch categories left behind.$^{48}$ For all its beauty and political importance, Pramoedya's dream of Kartini is a dream, her identification with the peasants, a fantasy. Kartini could criticize Dutch officers all she liked, but she remained within the limits of their prose.

\section{"Educating the Javanese": Kartini's Festival of the Indies}

Kartini's letters are the product of imagination: Kartini pictures herself in the eyes of Dutch friends and she pictures the world beyond her walls. It is the ambiguity of Kartini's position in her pictures which allows Pramoedya and Soeroto to imagine Kartini as they do. Kartini's writing, like mestizo culture, lacks an unequivocal origin; thus, Kartini becomes a symbol for the founding of any number of collectivities. ${ }^{49}$ Just as Kartini turned hindia molek into the Javanese landscape, Soeroto and Pramoedya project Kartini into their own social landscapes and make her image-and her people-their own.

Nowhere is this phenomenon more obvious than in Pramoedya and Soeroto's acclaim for Kartini's Note to the Dutch government entitled "Educate the Javanese." 50 Soeroto believes it marks the "peak of Kartini's career as a theorist on the problems of Javanese society."51 Pramoedya takes it as a courageous declaration of Kartini's views.

With refined words, she faced the colonial government and laid out what she felt was the right of her people, the right not to say "amin."

Both depict the Note as a coherent manifesto, reflecting their young heroine's plan of action. Soeroto sees Kartini promoting the Javanese language; Pramoedya sees her demanding her people's rights. Selectively cutting and pasting the document, both generate a message to prove what Kartini really meant.

In reassembling "Educate the Javanese!" to fit their fantasies, both Soeroto and Pramoedya leave a good deal of information out. A closer look at the uncut text reveals what a strange manifesto it is. Some curious images appear in the parts of the Note that Pramoedya and Soeroto discarded. As in her letters, Kartini writes of knowledge and prestige as if they were pretty things one might eat. The Javanese are children, dazzled by the baubles of pomp and prestige, but their appetites can be turned to Kartini's advantage. If the government acts enthused, the Javanese, just like preverbal children, will appropriate their idol's desires. ${ }^{53}$ The Regents will take Kartini's "medicine" if the government coats her proposal

\footnotetext{
48 See Kenji Tsuchiya, "Javanology and the Age of Ranggawarsita: An Introduction ot Nineteenth Century Javanese Culture" in Reading Southeast Asia, ed. Takashi Shiraishi (Ithaca: Cornell Southeast Asia Program, 1990), pp. 75-109, for the history of Javanology and its role in the demise of Java's written tradition. To understand the appeal of Javanology, it seems important to consider the anxieties which led the Dutch to focus the "light" of science on the "dark" world of the cultural unknown. Takashi Shiraishi "Before Dawn: A Note on 19th Century Java," (typescript, 1989) describes the technological, economic, and social roots of both the village underworld and the Dutch ethici who, at the turn of the century, accelerated colonial penetration and control. Kartini's awkwardness is not identical to that of her Dutch lady friends, but her response clearly adopts the technologies which emerged to combat their fears.

49 Jacques Derrida, "Declarations of Independence," New Political Science 15 (1986): 4-15, deconstructs another myth of national origins.

50 "Educate the Javanese," trans. by Jean Taylor of "Geef den Javaan Opvoeding," Indonesia 17 (April 1974): 83 98.

51 Soeroto, Kartini, p. 295.

52 Pramoedya, Panggil Aku Kartini Sadja, vol. 1, p. 166.

53 Kartini, "Educate the Javanese," p. 89.
} 
with sugar and presents it in a shining wrapper. ${ }^{54}$ Things get even stranger when Kartini switches perspectives and points her social telescope at Holland. There she finds dear Dutch children eager to learn of the beautiful lands and warm brown people they will rule. In addition to "global education," Kartini proposed a Javanology road show, a "Festival of the Indies" complete with handicrafts, grass huts, and "real Javanese."55 Pramoedya and Soeroto set aside these images as well. Kartini and the community which shares her perspective occupy a very strange place indeed.

Elsewhere in the document, we find other indications of the limits of Kartini's imagined community. Kartini makes her case by citing empirical evidence. "Cases are known," Kartini tells us, of a Javanese girl who benefitted greatly from kind Dutch women ${ }^{56}$ and a wise Javanese prince who sent his children to school. ${ }^{57}$ On closer inspection, all of these "cases" derive from a single life-Kartini's own. Referring to herself as if to a random member of her collective, Kartini is both the representing and the represented in her text. The argument is circular: her life is her own best evidence for promoting improvements in the conditions of her life.

Kartini's idiom may seem unusual, but "Educate the Javanese!" bears a resemblance to later writing of the Indonesian "awakening." Whether they read Kartini or not, in the 1910s, leaders of the "pergerakan" or movement also used Ethical language to mobilize their groups. ${ }^{58}$ They created a hierarchy of the spirit but limited its scope to the inlander elite; they reversed the metaphor of dukun and doctors, this time degrading the Dutch. As a priyayi woman, Kartini lived a confined life. Her journeys were short, her fellow travelers were very few; the only people available to fill her hierarchy were her family and a few Dutch friends. Even more than the ideologues who followed her, Kartini cannot keep straight who is "us" and who is "them." Her mixed-up audience evokes mixed-up metaphors. The dukun are the educated (Javanese or Dutch?) who take their secrets to the grave, greedily hoarding their knowledge. ${ }^{59}$ Kartini is the doctor, but she is also a patient. "Teach the people in the Netherlands to ask themselves, What would the Netherlands be without the Indies?'," she writes, "and the Indies should be taught to ask, What would the Indies be without Holland?'"60 Kartini can no more imagine one without the other than she can cut her father's "secret telegraph cable to her heart." 61 Caught between linguistic worlds, Kartini is not sure where to go; Indonesia has not yet learned to speak.

\footnotetext{
54 Ibid.

55 Ibid., p. 92.

56 Ibid., p. 93.

57 Ibid., p. 89.

58 Takashi Shiraishi, An Age In Motion (Ithaca: Cornell University Press, 1990) interprets the language of the pergerakan. Tjipto (veteran of the Kartini Debating Club!) depicts an alternative hierarchy based on Javanese virtues drawn from the Dutch linguistic world (p. 126). Tjokro, like Kartini, is a "satriya under the government" (p. 62); just as Kartini stands defiantly beside the Resident while other wedding guests crouch, Tjokro stands beside the government representative while he bellows at the crowd. The dukun/doctor reversal appears in Mas Marco's radical attack on the "Ethical" policies of the colonial state (p. 83).

59 lbid., p. 88.

60 Ibid., p. 94.

61 Kartini, Letters of a Javanese Princess. With a Preface by Eleanor Roosevelt. Edited and with an introduction by Hildred Geertz (New York: Norton, 1964), p. 48.
} 


\section{Conclusions?}

With Tsuchiya's help, we can take a different view of Kartini and her myths. The "real" Kartini and all the Kartinis who followed her are products of the penetration of certain politics into certain texts. Her ambiguity presents both a challenge and a resource; she is a question which can only be silenced through force. We can never know Kartini's true intentions; even if we could return to her Jepara, her secret core lies everywhere and nowhere in her texts. What we can trace are the powers which have staked a claim on Kartini to turn her symbolic force to their benefit. Grounded in history and territory, Pramoedya and Soeroto's versions of Kartini's truth reflect different moments in Indonesia's past. New Kartinis will continue to be born as long as power demands it; we may follow this process, but we are unlikely to bring it to a close.

\section{An Afterthought}

Raden Ajeng Kartini freed herself from the narrow oppression of tradition, and the simple language of these letters chants a poem "From Darkness into Light." The mist of obscurity is cleared away from her land and her people. The Javanese soul is shown as simple, gentle, and less hostile than we Westerners had ever dared to hope. For the soul of this girl was one with the soul of her people, and it is through her that a new confidence has grown up between the West and the East. The mysterious "Quiet Strength" 62 is brought into light, it is tender, human and full of love, and Holland may well be grateful to the hand that revealed it. ${ }^{63}$

In a photograph featured in the Kartini Fund's Annual Report of 1926, a line of little girls, clad neatly in batik, takes turns washing their hands. The setting is a wellfurnished classroom, its shelves adorned by toy cars, pictures, and plants. The focal point is the gleaming modern faucet; to the left, a Dutch woman gazes at us placidly while another inspects the little girls' hands. It is a perfectly staged scene, but for one strange detail. Staring blankly at the camera, her back turned to her teachers, a little girl has pulled up her kain to reveal a snowy white petticoat underneath.

An important set of characters is missing from this story. Along with a host of Western scholars and journalists, the colonial government spawned Kartinis of their own. Years before the publication of Habis Gelap Terbitlah Terang, people in Holland flocked to Kartini lectures, chaired Kartini committees, and contributed to Kartini schools designed to bring meer licht to the Javanese soul. These Dutch men and women imagined a Kartini who represented all of the people of her color. They rejoiced at the love at the core of that "quiet strength"; now there was nothing to fear. What could better reflect what they found in Kartini's soul than the underwear beneath the little girl's kain?

The story of these Dutch Kartinis is an important one, for that little girl's bloomers reflect modern contradictions as well as colonial ones. Along with the structures of the colonial state, modern Indonesia has inherited many of its anxieties. The strangeness Kartini depicted remains today. A history of that strangeness and the institutions which have created and confronted it could explain why so much is at stake in the identification of Kartini with her people. Such a history would open onto much wider terrain. In appropriating Kartini, the New Order controls just one of the moments when its own Dutch "foundations" might show.

62 Couperus' gives this English translation of his famous term "Stille Kracht." It is already a "simple, gentle, less hostile" rendition of what is elsewhere translated as "The Hidden Force."

63 Louis Couperus in his foreword to Letters of a Javanese Princess, edited by Agnes Symmer, New York, 1920. 